\title{
SPOR VE REKREASYON ALANLARININ TASARIMINDA VE KULLANIMINDA ÇEVRESEL SÜRDÜRÜLEBiLIRLIK
}

\author{
Velittin BALCl ${ }^{1}$
}

Funda KOÇAK ${ }^{1}$

\section{ÖZET}

Bu çalışmanın amacı, spor ve rekreasyon alanlarının tasarımı ve kullanımı açısından, ekolojik çevreyle ilişkilendirerek sürdürülebilir spor alanlarının oluşturulmasının önemine dikkat çekmektir. Araştırma betimsel tarama yöntemi kullanılarak yayına hazırlanmıştr. Gelecekte rekreasyonel ve sportif faaliyetlere aktif katılımı sağlayabilmek ve organizasyonlar gerçekleştirebilmek için çevresel kaynakların doğru tüketilmesine intiyaç vardır. Bu, aynı zamanda spor tesislerinin sürdürülebilirlik anlayışı çerçevesinde beklentileri karşılayabilmesini sağlayacak bir uygulama olacaktır. Bu anlamda sportif faaliyetlerin sürdürülebilmesinin gündeme gelmesi ile günümüzde spor tesislerinin yeniden yapılandırılmasında ekolojik unsurların etkin olduğu plânlama arayışlarına dönük yaklaşımlar tartışılmaya başlanmıştır. Bu tartş̧maların odak noktasını, Ortak Geleceğimiz Raporu'nda [1] öngörülen "bugünün ihtiyaçlarını, gelecek kuşakların kendi intiyaçlarını karşılayabilme olanaklarından ödün vermeksizin karşılamak" ilkesini temel alan sürdürülebilirlik kavramı oluşturmaktadır. Spor ve rekreasyon alanları bir taraftan toplumun refahını ve yaşam kalitesini artırma gibi olumlu etkiler yaratırken, diğer taraftan da, iyi planlanmayan alanlarla ve etkinliklerle ekolojik ve sosyal çevrenin olumsuz etkilenmesine neden olabilmektedir. Bu nedenle spor ve rekreasyon alanlarının tasarımında ve etkinliklerin düzenlenmesine amaç, sürdürülebilir olmak, bugünkü ve gelecekteki toplumların yaşam kalitesine olumlu katkılar sağlamak olmalıdır. Sonuç olarak; sürdürülebilirlik kavramının sürekli olarak çevre ile insan arasındaki ilişkiye işaret etmesi ve sporun doğal çevre elemanlarına olan bağımlılı̆ı; spor endüstrisinin dikkatli bir biçimde planlanmasını ve yönetilmesini gerektirmektedir.

Anahtar Kelimeler: Sürdürülebilirlik, çevre, spor ve rekreasyon alanı

\section{ENVIRONMENTAL SUSTAINABILITY IN THE DESIGN AND USE OF SPORTS AND RECREATION AREAS}

\section{ABSTRACT}

The aim of this study is to examine the importance of environment in terms of design and usage of sports and recreation and to draw attention to sustainability concept in establishing sustainable sports areas. The research was in the form of descriptive survey method. Enabling to public to take part in recreational and sportive activities actively or sustaining the events of the sports is possible through the preservation of environmental sources as well as satisfaction given by the facilities to be constructed. In this context, approaches that tend to plan seeking in which ecological elements are efficient in the re-structuring of sport facilities have started to be points of discussion nowadays as a result of the fact that sustaining the sportive activities have become the item of agenda. The focal point these discussions is the concept of sustainability that takes the principle as basis "meeting today's needs without harming the sources that will be used by new generations for meeting their own needs" foreseen in Our Common Future Report [1]. Sports and recreation areas can cause the environment to be affected negatively due to not well planned events and areas as well as increasing the quality of society's well being and living. Therefore, the aim in designing recreation and sport areas and in the organization of events is that the development should be sustainable and should have positive contributions to the living quality of current and next societies. In conclusion, the fact that sustainability concept continuously refers to the relation between human and environment and that the sports depend on natural environment elements require a careful planning and management of the sports industry. Keywords: Sustainability, environment, sports and recreation area

${ }^{1}$ Ankara Üniversitesi, 50. Yıl Kampüsü, Spor Bilimleri Fakültesi, Gölbaşı, ANKARA. Yazışmadan sorumlu yazar: e-mail: vbalci@ankara.edu.tr 


\section{GíRiş}

İnsanlar, yüzyıllarca kendi yaşamlarını iyileştirmek adına doğaya hükmetmenin yollarını aramış, doğayı sadece kullanılacak, istediği hammaddeleri üretebilecek, sanayi atkklarıyla birlikte nükleer atıkları saklayacak bir alan olarak görmüştür.

Sürdürülebilirlik açısından doğal çevrenin kendini yenileyebilme yeteneğinin birçok değişkene bağlı olması ve bozulan doğal dengenin düzeltilme sürecinde daha fazla kaynak tüketilmesi gerekliliği bilinen bir gerçektir. Doğal çevrede yaşanan çevresel değişiklikler günümüzde her alanda olduğu gibi spor ve rekreasyon alanlarının tasarımında da sürdürülebilirlik yaklaşımının önemini ortaya koymaktadır.

Sürdürebilirlik kavramı, son yıllarda üzerinde çok konuşulan ve gündem oluşturan bir kavram haline gelmiştir. Birçok farklı alanda kullanılan sürdürülebilirlik kavramının temel özelliği, insanın geleceğini konu alması ve hangi alanda kullanılıyorsa o alandaki kaynakların korunmasına dayanmasıdır [2]. Bu bakımdan sürdürülebilirlilik kavramının temel dayanağı, teknolojik gelişmelerin bir sonucu olarak ortaya çıkan çevre problemlerinin ve yıkımlarının önüne geçebilmek ve doğal yaşam alanlarının korunmasına katkıda bulunmaktır.

Spor alanında ise çevresel sürdürülebilirlik kavramı sürdürülebilir gelişmenin bir parçası olarak karşımıza çıkmaktadır. Bu anlamda spor ve rekreasyon alanları için çevresel sürdürülebilirlik, tesislerin insan mutluluğu ve kaliteli yaşam için kullanılması, işlevsel ve niteliksel özellikleri ile kuşaklar boyu sürdürülebilecek organizasyonların oluşturulması ve bunların bütününün yönetilmesi şeklinde tanımlanabilmektedir.

Günümüzde stadyumlarve diğer spor yapılarının çok geniş işlevleri bulunmaktadır; spor yapmaya ayrılan küçük kulüp yapılarından, prestijli olimpik stadyumlara, yüzme havuzlarına, limanlara, buz pateni sahalarına, kayak atlama merkezlerine kadar pek çok farklı yapı bulunmaktadır. Bu farklıı̆a rağmen yapıların ortak özelliği antrenman yapan, yarışmalara katılan ya da sadece spor izleyicisi olanlara en fazla güven ve konforu sağlamaktır. Bu amaçlar tamamıyla çevre ve sürdürülebilir gelişmeyle örtüşmelidir [3].

Yukarıdaki tartışmaların ışı̆̆ında bu çalışmanın amacı; spor ve rekreasyon alanlarının tasarımı ve kullanımı açısından, ekolojik çevrenin önemine dikkat çekerek, bugünkü ve gelecekteki kullanıcılar için sürdürülebilir spor alanlarının oluşturulmasının önemini ortaya koymaktır.

\section{Sürdürülebilirliğin Tanımı}

İlk kez 1987 yılında Birleşmiş Milletler sponsorluğundaki Dünya Çevre ve Kalkınma Komisyonu'nun (WCED) yayınladığı “Ortak Geleceğimiz” raporunda ortaya atılan sürdürülebilirlik, belirli bir ekosistemin ya da sürekliliği olan herhangi bir sistemin kesintisiz, bozulmadan, aşırı kullanımla tüketmeden ve ana kaynaklara aşırı yüklenmeden sürdürülebilmesi yetkinliği olarak bilinmektedir [4]. Sürdürülebilirlik kavramı ve doğal çevrenin korunması, daha sonra Maastricht Anlaşması (Avrupa Birliği Antlaşması) ile kapsamlı olarak dört yönüyle şu şekilde tanımlanmıştır [5].

- Çevre kalitesini geliştirmek ve korumak,

- Insan sağlığını korumak,

- Doğal kaynakların dikkatli ve akılcı kullanımını sağlamak,

- Bölgesel ya da evrensel tüm çevresel problemleri uluslararası düzeyde ele almak ve değerlendirmek. 
Sürdürülebilirlik kavramının çevresel yönü insan faaliyetlerinin içinde yer aldığı doğal çevre ile ilişkilidir. Yine Ortak Geleceğimiz raporuna göre [1] "eğer intiyaçlar sürdürülebilir bir çevrede karşılanacaksa, dünyanın doğal kaynakları korunmalı ve güçlendirilmelidir". Bu nedenle enerjinin ve yenilenemeyen malzemelerin küresel ölçekte hızla tüketimi karşısında, kaynak kullanımında yeni bir yaklaşım oluşturulması sürdürülebilirliğin diğer bir temel bileşenidir.

Sürdürülebilirlik kavramı 1980'lerden itibaren uluslararası çevresel tartşmalarda kalkınma, uygulamalı bilim, çevresel ve uluslararası politika alanlarında çok yönlü olarak incelenen ve odak noktası haline gelmiş olan bir kavram olmasına rağmen anlamı ve tanımı üzerine çok az fikir birliği sağlanmış bir kavramdır [6]. Sürdürülebilirlik olgusu, çevresel anlam ağırlıklı olarak ortaya çıkmasına rağmen 2000'lerde çevresel boyutları yanında ekonomik, sosyal, kültürel ve teknolojik olgularla bütünleşen bir kavram halini almıştır. Sürdürülebilirlik sadece çevre korumanın ön plana çıktığı bir gelişme anlayışını ifade etmemekte, gelişmeye ilişkin bütün ekonomik, mali ve ticari politikaların; ekonomik, sosyal ve çevre ile ilgili açılardan uyumlaştırıldığı bir süreç olarak karşımıza çıkmaktadır [7].

Mazurkiewicz [8]'e göre ise çevresel sürdürülebilirlik kurum ve kuruluşların üretimlerinde ve tesis planlamalarında, atıkları ve zararlı salınımları en aza indirmek, kaynakların kullanımında verimliliği artırmak ve ülke kaynaklarından gelecek nesillerin üst düzeyde yararlanmalarını sağlamak olarak tanımlamıştır.

Görüldüğü gibi çok boyutlu bir kavram olan sürdürülebilirliğin en çok önem taşıyan yönünün çevre ile ilgili olduğu ifade edilebilir. Çünkü doğal çevre üzerindeki yaratılan herhangi bir olumsuzluk bir daha geri dönülemez şekilde tüm canlıların yaşamını tehdit etmektedir.

\section{Yeşil Tasarım ve Sürdürülebilirlik}

Sürdürülebilir tesisler "enerjiyi daha verimli kullanan düzenleme materyallerini birleştirerek çevreyi koruyan yapılar" olarak tanımlanabilir [9]. Yeşil tasarımların odak noktası kar elde etmeyi birincil amaç olarak görmeden insani ve ekolojik değerlerin en üst düzeyde korunmasıdır. Yeşil tesisler uzun vadede çevresel kazanç sağlayabilmek ve kullanımlarının sürekli olabilmesi için enerji-verimli süreçlerden yararlanırlar [10]. Inskeep [11]'e göre rekreasyon alanlarının çevre üzerine olumsuz etkileri olarak su kirliliği, hava kirliliği, gürültü kirliliği, atık sorunu, ekolojik bozulmalar, çevresel tehlikeler, arkeolojik ve tarihi yerlerin tahrip edilmesi, arazi kullanım sorunları olarak sıralanmaktadır. Bu anlamda spor ve rekreasyon alanlarının tasarımında sürdürülebilirlik yaklaşımı; bir çeşit yeniden düzenleme, yenilenebilen ve yenilenemeyen kaynaklar için koruyucu bir yaklaşımdır [12]. Sürdürülebilirlik girişimleri çevrenin lehinedir [13]. Spor ve rekreasyon alanlarında sürdürülebilir bir yaklaşım, bu alanlarda kullanıcının sağlığını korumak, çalışan verimliliğini arttırmak, kaynaklardan daha etkin bir şekilde yararlanmak ve çevresel etkileri azaltmak yönündedir [14].

Spor ve rekreasyon alanları oluşturmada amaç, sosyal yaşamı iyileştirme ve insan sağlığını korumak olmasına rağmen, tesislerin çevreye getirdiği yük ve zarar artık tartş̧ılabilir bir noktaya gelmiştir. Tablo 1'de bazı spor ve rekreasyon alanların çevre üzerindeki olumsuz etkileri gösterilmiştir. 
Tablo 1. Bazı spor ve rekreasyon alanlarının çevresel etkileri

\section{Spor Dalları}

\begin{tabular}{|c|c|}
\hline \multirow{7}{*}{ Golf } & Nitelikli arazi kullanımı (tarım arazisi, doğal yaşam alanı vb.) \\
\hline & Doğal bitki örtüsünün tahrip edilmesi ve ağaç kesilmesi \\
\hline & Yüksek miktarda su tüketimi \\
\hline & Uygun olmayan zirai ilaç ve gübre kullanımından kaynaklanan toprak ve su kirliliği \\
\hline & Yakıtlardan ve kimyasallardan kaynaklanan toprak ve su kirliliği \\
\hline & Habitatın rahatsız edilmesi \\
\hline & Zemin bakım araçlarının kullanımından kaynaklanan gürültü \\
\hline \multirow{9}{*}{ Kayak } & Doğal bitki örtüsünün tahrip edilmesi \\
\hline & Koruma altındaki ormanların bütünlüğünün bozulması ve seyrekleşmesi \\
\hline & Toprak sıkışması \\
\hline & Yakıt sızıntıları nedeniyle toprakta meydana gelen kimyasal kirlilik \\
\hline & Toprak kayması, toprak erozyonu, çı̆̆ \\
\hline & Alt yapı ve üst yapı çalışmaları için orman arazisinin kullanımı (park yerleri, yollar, oteller vb.) \\
\hline & Katı atık üretimi \\
\hline & Gürültü kirliliği \\
\hline & Yaban hayatta bozulma \\
\hline \multirow{3}{*}{ Yüzme } & Yüksek miktarda su tüketimi \\
\hline & Zararlı kimyasalların kullanımı \\
\hline & Yüksek enerji tüketimi \\
\hline
\end{tabular}

\section{Çevresel Etkileri}

\begin{tabular}{|c|c|}
\hline \multirow{2}{*}{ Buz Sporları } & Buz soğutma ve ısıtma işlemleri için yüksek enerji tüketimi \\
\hline & Ozon tabakasına zarar veren karbon salınımına neden olan sıvı atıkların doğaya salınımı \\
\hline \multirow{10}{*}{ Futbol } & Yüksek miktarda su tüketimi \\
\hline & Zirai ilaç kullanımından kaynaklanan su ve toprak kirliliği \\
\hline & Zemin bakım araçlarının yakıtlarından ve kimyasalların kullanımından kaynaklanan su ve \\
\hline & toprak kirliliği \\
\hline & Zemin bakım araçlarının kullanımından kaynaklanan gürültü \\
\hline & Işıklandırma için yüksek enerji kullanımı \\
\hline & Gürültü kirliliği \\
\hline & İzleyici araçlarından kaynaklanan hava kirliliği \\
\hline & Fosil yakıtların yarattı̆ı çevre kirliliği \\
\hline & Maç günlerinde atıklardan kaynaklanan çevre kirliliği \\
\hline \multirow{7}{*}{ Araba Yarışı } & Pistlerin inşası için doğal yaşam alanlarının tahrip edilmesi \\
\hline & Orman alanlarının tahrip edilerek flora ve faunaya zarar verilmesi \\
\hline & Işıklandırma için yüksek enerji kullanımı \\
\hline & Yarışların gerçekleşmesinde kullanılan destek hizmetlerinin yarattı̆ı enerji tüketimi \\
\hline & Zararlı gaz salınımlarının oluşturduğu hava kirliliği \\
\hline & Gürültü kirliliği \\
\hline & Park alanları için yeni alanların açılması \\
\hline \multirow{7}{*}{$\begin{array}{l}\text { Rekreasyon Alanları } \\
\text { (Büyük parklar, doğal } \\
\text { ve suni göller, eğlence } \\
\text { parkları ve aqua } \\
\text { parklar) }\end{array}$} & Gürültü kirliliği \\
\hline & Doğal bitki örtüsünün tahrip edilmesi \\
\hline & Habitatın zarar görmesi \\
\hline & Fosil yakıtların tüketilmesinden kaynaklanan hava kirliliği \\
\hline & Eğlence parklarında makinelerin çalıştırılması için yüksek enerji kullanımı \\
\hline & Kat attk üretimi \\
\hline & Su parklarında yüksek enerji ve su tüketimi \\
\hline
\end{tabular}

Kaynak: Chernushenko et. all (2001)'den yazarlar tarafindan uyarlanmıştır [15]. 
Tablo 1'e bakıldığında spor ve rekreasyon alanlarının kendilerine özgü ihtiyaçlarından kaynaklanan pek çok olumsuz çevresel etki ortaya çıkmaktadır. Bu etkiler spor tesisinin sahip olduğu alana, konumlandırıldığı yere, kullanım kapasitesine, su ve enerji tüketimine göre değişik boyutlarda olmaktadır.

Tablo 2'de golf sporunun Tablo 1'de belirtilen çevresel etkileri ayrıntı olarak gösterilmektedir. Son yıllarda tüm dünyada golf sporuna olan ilgi artmaktadır. Oldukça geniş araziye ihtiyaç duyan golf sahaları genellikle doğal güzellikleri ile ünlü ve ulaşımı kolay bölgelere yapılmak istenmektedir. Ayrıca bu sahalar konaklamalı turizmin yoğunlaştı̆ı bölgelerde yatırım haline dönüştürülmektedir. Tablo 2'ye bakıldığında golf sahalarının çevresel yönleri ve iyi bir planlama yapılmadığında ekolojik çevre üzerindeki etkileri ayrıntılı olarak görülmektedir.

İyi planlanmayan golf sahalarının Tablo 2'de olumsuz çevresel etkilerinin yanında tarımsal üretimin sağladığı beslenme sürdürülebilirliğine etkisi de ayrı bir tartışma konusudur.

Spor ve rekreasyon alanlarındaki önemli çevresel etkileri en aza indirmek ve çevresel sürdürülebilirliği sağlamak için tesisleri tasarlamadan önce şu önemli sorulara cevap bulunması gerekmektedir.

- Bu tesise ihtiyaç var mı?

- Ne tür bir tesis potansiyel kullanıcıların ihtiyaçlarını en iyi şekilde karşılar?

- Tesisin uzun vadeli tüketimleri (finansal, sosyal ve çevresel) neler olacak ve bu bedelleri kimler/hangi kaynaklar/canlılar ödeyecek [15]?

- Bu tesis inşası aşamasında hangi canlı habitatını tehdit edecek ve oradaki yaşamın sürdürülebilirliğinde hangi etkileri nasıl yaratacaktır?

$\mathrm{Bu}$ kritik sorular tam olarak karşılığını bulursa ve intiyaçlar doğru olarak belirlenebilirse sağlanacak enerji tasarrufu ve çevresel maliyetler ortaya çıkar, çatışmalar engellenir ve finansal ya da ekolojik yıkımlardan kaçınııı [15].

Çevresel etkileri en aza indirmek ve çevresel sürdürülebilirliği sağlamak için yapılması gerekenler aşağıda ayrıntılarıyla irdelenmiştir. 
Tablo 2. Golf sahalarının çevresel yönleri ve çevreye etkileri

\begin{tabular}{|c|c|c|}
\hline Aktiviteler & Çevresel Yönleri & Çevresel Etkileri \\
\hline \multirow{7}{*}{ 1. Çim Yönetimi } & Çim Biçme & $\begin{array}{l}\text { Ekosistemin bozulması } \\
\text { Organik atık üretimi (çim biçme) } \\
\text { Su organlarında ötrofikasyon }\end{array}$ \\
\hline & Gübre Uygulaması & $\begin{array}{l}\text { Ötrofikasyon } \\
\text { Su ve toprak kirlenmesi }\end{array}$ \\
\hline & Böcek İlacı uygulaması & $\begin{array}{l}\text { Su ve toprak kirlenmesi } \\
\text { Zararlı atklar (Boş konteynırlar) } \\
\text { İnsan sağlığı tehditleri }\end{array}$ \\
\hline & $\begin{array}{l}\text { Toprak koruma } \\
\text { (Havalandırma vb.) }\end{array}$ & $\begin{array}{l}\text { Ekosistemin bozulması } \\
\text { Gürültü kirliliği }\end{array}$ \\
\hline & Toprak Boşaltma & Hidrolojik bozulma \\
\hline & Sulama ve pompalama & $\begin{array}{l}\text { Su kaynağı tükenmesi } \\
\text { Enerji kaynağı tükenmesi }\end{array}$ \\
\hline & Kimyasal depolama & $\begin{array}{l}\text { Insan sağlığını tehdit edici riskler } \\
\text { Su ve toprak kirlenmesi }\end{array}$ \\
\hline \multirow{2}{*}{ 2. Malzeme Bakımı } & $\begin{array}{l}\text { Malzemelerin } \\
\text { Temizlenmesi }\end{array}$ & $\begin{array}{l}\text { Su kaynağının tükenmesi } \\
\text { Su kaynağının kirlenmesi } \\
\text { Katı atık kirliliği }\end{array}$ \\
\hline & Makinelerin tamiri & $\begin{array}{l}\text { Toprak kirliliği } \\
\text { Su kirliliği }\end{array}$ \\
\hline 3. Sahaların Yeniden Tasarımı & Toprağın Taşınması & Ekosistemin bozulması \\
\hline
\end{tabular}

$\begin{array}{ll} & \text { Su kirliliği } \\ & \text { Yenilenemeyen kaynakların tükenmesi } \\ \text { Makineler (çim biçme } & \text { Yenilenebilir kaynakların tükenmesi } \\ \text { makinesi, traktör vb.) } & \text { Toprak kirliliği } \\ & \text { Zaralı atık üretimi }\end{array}$

\section{Araç-Makine İşleri}

\begin{tabular}{ll}
$\begin{array}{l}\text { Golf arabası } \\
\text { (yakıt tahrikli) }\end{array}$ & $\begin{array}{l}\text { Hava kirliliği } \\
\text { Yenilenemeyen kaynakların tükenmesi } \\
\text { Gürültü kirliliği }\end{array}$ \\
\hline Elektrikli golf arabası & Enerji Kaynaklarının tükenmesi \\
\hline
\end{tabular}

Kaynak: Koch 1998 [15]. 


\section{Spor ve Rekreasyon Alanlarının Tasarımında Sürdürülebilir Öncelikler}

Ries ve ark. [16]'a göre sürdürülebilir düzenleme, bir tesisin hizmet süresi ve doğal çevrenin korunmasında önemli kazançlar sağlayacak ve tesisin kullanım potansiyelini artrracaktır. Çevre ve sürdürülebilir gelişim bakış açısıyla değerlendirildiğinde, spor ve rekreasyon alanı olarak inşa edilen binaların ve diğer yapıların şu kriterlere uyması gerekmektedir.

\section{Konumlandırma}

Dünyada küresel ısınmayla birlikte bir iklim değişikliğinin yaşandığı gözlenmektedir. Bu alanların planlaması yapılırken uzun vadede etkisini gösterecek olan iklim değişiklikleri de göz önünde bulundurularak oluşacak şartların iyi analiz edilmesi gerekmektedir [17].

Spor ve rekreasyon alanları için yer seçiminde ormanlık alanlardan, tarımsal üretim alanlarından ve doğal yaşam alanlarından uzak durulmalı, verimsiz arazilerin seçilmesi teşvik edilmelidir. Ayrıca tesislerin inşa edildikleri alana uyumlu olması estetik görünümün yanında kullanım kolaylığıyla da ilgilidir. İyi planlanan bir tesis toplu taşımaya yakın olması, arabalar için park alanları bulundurma gibi yardımcı planlama faktörlerini de içermelidir [3].

Bazı sporlara özgü tesislerde (golf sahası, stadyum, yüzme havuzu, buz pisti vb.) kullanılan kimyasalların toprağa ve yer alt sularına karışarak ciddi bir kirlilik yarattı̆ı konusu da bir diğer önemli kaygıdır. Planlama aşamasında kullanılacak olan toprağın cinsi ile ne kalınlıkta olacağının iyi belirlenmesi ve inşa sonrasında bu tesislerin bakımının iyi yönetilmesi durumunda çevresel kirliliğin büyük ölçüde ortadan kalkması mümkündür. Örneğin; spor sahalarında ve rekreasyon alanlarında çimi beslemek üzere gübreleme yapmadan önce toprak türü, su tutma kapasitesi, kullanılan su miktarı ve bitki türleri gibi etkenleri değerlendirmek gerekir.

\section{Atıkların Önlenmesi ve AzaltıIması}

Doğal kaynakların verimli kullanımı sürdürülebilirliğin en temel ilkesidir. Klasik yapılar, su, elektrik ve doğal kaynakları gereksiz yere fazla miktarda tüketmektedirler. Sürdürülebilir gelişme için yapı malzemelerinde geri dönüşümlü ürünler kullanılmalıdır [18].

Hızla gelişen geri dönüştürülebilir ürün piyasası sayesinde günümüzde attklar, attk depolama alanlarında tekrar kullanılmak üzere dönüştürülmektedir [19]. Bu anlamda atıkların geri dönüşümü konusunda titizlik gösterilmelidir. Bu amaçla atık su eliminasyonu, atk yönetimi, duman temizleme sistemleri, elektrik akımı, eskimiş alt yapı malzemeleri, ısıtma, soğutma ve havalandırma sistemleri yapının minimal düzeyde kirliliğe sebep olması ve enerji tüketmesi açısından düzenli olarak kontrol edilmeli ve bakımları yapılmalıdır [3]. Çevreye saygı, farklı kural ve aktivitelerin yerine getirilmesi anlamına gelmektedir ve tesislerin tasarımında aşağıda belirtilen özelliklere uyulmalıdır.

- Çevresel etki çalışmaları her yeni inşaattan veya büyük yeniden yapılanma projesinden önce yapılmalıdır.

- Teknik süreçte kullanılan materyallerin küresel çevre etkilerini araştırmak için kullanım süresi analizlerinin yapılması gerekmektedir.

- Mümkün olduğunca, var olan kurulum, yeniden yapılandırmanın ardından, değişen ihtiyaçlara ve çevreyi koruma gerekliliklerine uygun olarak tekrar kullanılmalıdır.

- Yenilenebilir enerjinin kullanımı (jeotermal güneş ve rüzgar gücü) yapının geniş alanlarını uygun donanımın (güneş enerjisi panelleri ve rüzgar tribünü) kurulumuna uygun olmasından dolayı en üst düzeyde artırılmalıdır.

- Kurulumu yapılan sıhhi tesisat (tuvaletler, çöp kutuları) sayısının dağılımı yapıyı kullanan kişi 
sayısını karşılamalıdır.

- Tüm bu kurulumlar modern teknolojiye uygun olmalıdır.

- Kimyasal zehirleyici ve tehlikeli maddelerin kullanımı yasaklanmalıdır. Kullanılması gerektiği durumlarda kanuni kurallar çerçevesinde yapılmalıdır. Aynı zamanda bu maddelerin depolanması ve saklanması hususuna da özel dikkat gösterilmelidir [3].

\section{Enerji ve Su Korunumu}

Özellikle de topluma su akışı sağlanıyorsa kaynakları paylaşmak (su, toprak, enerji) yerel halk için bir dezavantaj oluşturmamalıdır. Spor tesislerinin tarım arazilerine, ormanlık alanlara, yer altı suları, kaynak suları ve nehirlerin bulunduğu yerlere inşa edilmesinden kesinlikle kaçınmak gerekir. Inşaat yapılırken etki çalışmaları kaynaklara ulaşım bakımından oluşan değişiklikleri kaydetmeli ve inşaatın yapımından sorumlu kişiler yerel halkın bu durumdan etkilenmeyeceğine dair sorumluluğu üzerine almalıdır [3].

Rekreasyon alanları ile ilgili kaygıların en başında yoğun su kullanımı konusu gelmektedir. Spor ve rekreasyon alanlarında genellikle su tüketimi oldukça fazladır ve bu açıdan su tasarrufu önemli bir konu başlığıdır. Yapılacak olan teknolojik iyileştirmeler ve planlamalarla bu sorunun aşıması mümkündür ve tesislerin kendi atk su kaynaklarının yaratımasına dikkat edilmelidir. Tesislerin olduğu bölgeye uygun çim kullanımı sulama ihtiyacını azaltır bu da kurak mevsimlerde önemlidir. Ayrıca, günün uygun saatlerinde sulama yapmak, yağmur suyu ve atık su gibi sulama araçlarını da keşfetmek su tasarrufu sağlar.

Tesisleri yapanlar, yeni nesil enerji verimli uygulamalardan en iyi şekilde yararlanmalıdırlar [12]. Enerji verimliliği, sürdürülebilir alan tasarımın temel taşlarından birisidir. Enerjinin kullanımı ve üretimi, küresel mevsim değişiklikleri ve hava kirliliğine etki eden en temel unsurlardır. Enerji verimliliğini arttrmak ve yenilenebilir enerji kaynaklarını kullanmak, olası enerji kesintilerini azaltmak, hava kalitesini geliştirmek ve küresel ısınmanın etkilerini azaltmak için etkili yollardır. Arttırımış enerji verimliliği örnekleri, en üst düzeyde yapılanmış yalıtım, ısı geçirgenliği az olan çift camlar ve yüksek verimliliğe sahip ısıtıcılar ve diğer uygulamalardan oluşmaktadır [16]. En iyi şekilde tasarlanmış bina yalıtımları ısıtma, havalandırma ve iklimlendirme donanımlarının, ısıtma ve soğutma masraflarının azaltılmasında önemli yararlar sağlar [20].

Ayrıca bazı etkinliklere özgü kullanılan araçların enerji kaynakları da birer sorun olarak öne çıkmaktadır. Akaryakıtla çalışan araçların güneş enerjisi ve biyoenerji ile çalışanlara dönüştürülmesi gibi çalışmalar çevreci enerji kullanımının öne çıktı̆̆ durumlardır [17]. Aydınlatma sisteminde ise enerji verimli ampuller ve reflektörler (komşu bölgelere ve konutlara daha az ışık yansıtan) ile enerji tüketiminin daha kolay kontrol edilebileceği bilgisayarlı enerji yönetim sistemlerine başvurulmalıdır [15]. Gün ışığından daha fazla yararlanmayı sağlayan tasarımlar geliştirilmelidir.

\section{Çok Amaçlı Tesisler}

Spor tesisleri çok amaçlı sosyal kullanımlar için tasarlanmalı ve geliştirilmelidir. Tasarımı ve işlevi ile spor tesisleri ve yapıları yerel halkın aktivitelerini gerçekleştirebilecekleri bir yer olmalıdır. $\mathrm{Bu}$, çok amaçlı tasarımla yerel okulların beden eğitimi dersi için donanımların sunulmasına, yerel organizasyonlara, yaşlı kişiler, kadınlar ve gençlerden oluşan gruplara oda kiralanmasına kadar geniş bir kullanımı içine alır [3]. Birden fazla amaca yönelik tesislerin yapılması, gereksiz yapılaşmadan uzaklaşmayı sağlamaktadır.

Çok amaçlı tesislerin farklı boyutları bulunmaktadır.

- Binaların tasarımı yapı malzemeleri ve bakımı uzun ömürlü kullanım sunmalıdır. 
- Özel bir amaç için inşa edilmiş prestijli ancak uzun vadeli kullanım potansiyeli düşük ve bakımı yerel makamlara yük olacak binaların yapımından kesinlikle kaçınmak gerekir.

- Yapının çeşitli kullanım özelliklerinin bulunması gerekmektedir (farklı spor etkinliklerine açık olma, sosyal aktivitelerde kullanabilme vb.).

- Sık olmayan kullanımlar için sökülebilir kurulumlar tercih edilmelidir [3].

\section{Biyolojik Çeşitliliğin Korunması}

Biyolojik çeşitlilik canlı organizmalar ile onların bulunduğu ekolojik ortamlar arasındaki çeşitliliği ve değişkenliği ifade eden dinamik bir sistemdir. Biyolojik çeşitliliğin korunması ekosistemlerin düzgün olarak çalışmasını sağlar. Ekosistemler bitki, hayvan ve mikroorganizma toplulukları gibi canlılar ile onların ilişki içinde yaşadıkları toprak, su, hava, mineraller gibi cansızların karşılıklı etkileşim içinde oluşturdukları dinamik bir bütün olarak ifade edilebilir [21].

Spor alanları planlanırken ve inşa edilirken bu arazide yaşayan canlı türlerinin özellikle de korunmakta olan türlerin varlıklarını devam ettirebilmeleri ve rahatsı edilmemeleri temel hedef olmalıdır. Canlı türlerinin doğal yaşam alanlarda, kuluçka ve dinlenme dönemleri iyi belirlenip herhangi bir rahatsız edici müdahale engellenmelidir.

Birçok canlı türünün, doğada yaşamlarını sürdürdükleri göz önünde bulundurularak doğa yapısında oluşacak değişimlerin boyutuna dikkat edilmelidir. Bitki türlerinin zarar görmesini ve yok olmasını önlemek için bir takım yöntemler bulunmalıdır. Korunması gereken bitkiler sökülüp inşa süreci boyunca bir serada saklanarak süreç sonunda tekrar eski yerlerine geri yerleştirilmelidir. Böylece bu türlerin inşa sürecinden zarar görmeden çıkmaları sağlanmalıdır [17].

\section{Dünya'da Yeşil Tasarıma ve Çevresel Sürdürülebilirliğe Uygun Yapılar}

Yukarıda ayrıntılarıyla irdelenen tüm bu kriterleri genel bir bakış açıyla değerlendirdiğimizde iyi bir planlama sonrasında sürdürülebilir çevresel çözümlerin mümkün olduğunu görmekteyiz. Dolayısıyla, sürdürülebilir bir yaklaşımla spor ve rekreasyon alanlarının inşa ve yönetim süreçlerini kontrol etmek ve bu süreçlere katkıda bulunmak oldukça önemlidir.

Kaynak kullanımında temel olumsuzlukların ve çevresel etkilerin önlenebilmesi için yaşam tarzında ve sisteminde temel değişiklikler yapılması gerekmektedir [22]. Teknolojik gelişmelerin akılcı kullanımıyla günümüzde spor ve rekreasyon alanlarının tasarımında da çevresel sürdürülebilirliğe uygun pek çok gelişme göze çarpmaktadır.

Sürdürülebilirlik kavramı spor organizasyonu olarak ilk kez 2000 Sydney Olimpiyatları'nda benimsenmiş, Sydney Olimpiyat Komitesi (SOCOG) tarafindan, "yeşil bir olimpiyat" için ekolojik açıdan gerçekçi ölçütler ve akılcı kararlar içeren birtakım çevresel ilkeler belirlenmiş ve olimpiyat hazırlığında SOCOG ve Greenpeace birlikte çalışmışlardır [23].

Belirlenen ilkeler sürdürülebilir gelişme ve çevresel sorumluluk sahibi bir yönetim için geçerli olan ekolojik ölçütlerdir. Bu ölçütlere göre gerçekleştirilen sürdürülebilir düzenlemeler olimpiyat köyünün yerinin seçimiyle başlamıştır. Sydney Olimpiyat Köyü, Homebush Körfezi'nde terk edilmiş bir sanayi bölgesini, devlet mezbahasını ve kent çöplüğünü de içine alan verimsiz bir arazi üzerine kurulmuştur. Olimpiyat köyünün inşasında güneş evleri kullanılmış ve kendi enerjisini üreten bu akıllı evler, oyunlar sonrasında yerleşime açılmış ve dünyanın en büyük güneş enerjili konut projesi elde edilmiştir. Bunun yanında Olimpiyat köyünün yapımına başlanmadan önce, dünyada bilinen ve türü tehlikede olan sarı ve yeşil çıngıraklı kurbağa cinslerinden birinin Homebush Körfezi'nde yaşadığı anlaşılmış ve kurbağa habitatının korunması için olimpiyat planları değiştirilmiştir. Ayrıca olimpiyat arazilerindeki böcek kontrolünde kimyasal yöntemlerden kaçınılmıştır. Mevcut habitatın 
devamını sağlamak üzere vahşi hayat habitatının kesilmesi ve yerli bitki türlerinin korunmasını destekleyen peyzaj programları geliştirilmiştir [23].

Günümüzde bilindiği gibi stadyumlar seyirci kapasitelerinin yüksek olması nedeniyle ışıklandırmalarında çok fazla enerji tüketimine neden olmaktadırlar. Harcanan bu enerji de genellikle şehir şebekesinden sağlanmaktadır. Bu anlamda Tayvan'ın Kaohsiung kentinde inşa edilen Dragon Stadyumu kendisinden sonra gelen ya da yenilenecek olan stadyumlara çevresel sürdürülebilirlik açısından çok iyi bir örnek oluşturmaktadır. Ejderha görünümünde tasarlanan bu stadyum tamamen güneş enerjisiyle çalışan dünyanın ilk stadyumu olma özelliğini taşımaktadır. Elli bin kişi kapasiteli stadyumun çatısı 8844 adet güneş paneli ile kaplanmıştır. Bu paneller çatıda toplam 14 bin 155 metrekarelik bir alanı kaplamaktadır. Panellerin gündüz ürettiği enerji, geceleri stadyumun aydınlatılması için kullanılmaktadır. Stadyumda müsabaka olmadığı zamanlarda üretilen elektrik enerjisi kent şebekesine verilmekte böylece yapı çevresindeki yerleşim birimleri için enerji üreten bir santral görevi üstlenmektedir. Stadyum kendi enerjisini kendisinin üretmesinin yanında yıllık 1,14 milyon kilovat saat elektrik üretimi ile yıllık 660 ton karbondioksitin doğaya salınmasını da engellemektedir [24].

Sürdürülebilir tesislere diğer bir örnek de Dubai'de ünlü golfçü Tiger Woods tarafindan tasarlanan Tiger Woods Dubai'dir. Dünyanın en iyi golf sahaları arasında gösterilen tesis çöl coğrafyasında kum üzerine inşa edilmiştir. Golf sahasının yapımı aşamasında hiç bir çevresel yıkım söz konusu olmamıştır. Bunun yanında verimsiz arazi kullanılabilir duruma getirilmiştir. Ayrıca Tiger Woods Dubai'nin bakımı için gerekli olan su ihtiyacı denizden taşınan suyun arıtılmasıyla karşılanmaktadır [25].

Yukarıdaki örnekler spor ve rekreasyon alanlarında sürdürülebilirliğin sağlanmasıyla ilgili öncü projelerdir. Her geçen gün gelişen teknoloji ile bu örneklere yenileri de eklenecektir.

\section{Türkiye'de Spor Alanında Çevresel Sürdürülebilirliğin Sağlanması İçin Girişimler}

Çevre politikalarının hedefi, insanların sağlık ve mutluluk içerisinde yaşayabilecekleri sürdürülebilir bir ortam sağlamak, hava, su ve toprağı, bitki ve hayvanlar alemini insanların zararlı etkilerinden korumak ve insanların faaliyetlerinden kaynaklanan zararları ortadan kaldırmaktır [26].

1983 yılında yürürlüğe giren çevreyi bir bütün olarak gören 2872 sayılı Çevre Kanunu’nun amacı sadece çevre kirliliğini incelemekle sınırlı olmayıp, aynı zamanda doğal ve tarihi varlıklar ile doğanın gelecek kuşaklarca kullanılabilmesini sağlayacak şekilde korunmasını hedeflemektedir. Çevre Kanunu ile birlikte ülkemizde spor ve rekreasyon alanlarını doğrudan ilgilendiren çevrenin korunması, kirliliğin önlenmesi ve denetim altnna alınması ile ilgili Milli Parklar Kanunu (1983) ve Kıyı Kanunu (1990), Gürültü Kontrol Yönetmeliği (1986), Su Kirliliği Kontrol Yönetmeliği (1988), Kıyı Kanununun Uygulanmasına Dair Yönetmelik (1990), Katı Atık Kontrol Yönetmeliği (1991), Çevresel Etki Değerlendirme Yönetmeliği (2003) ve Tehlikeli Kimyasallar Yönetmeliği (2001) yürürlüktedir [27]. Bu yönetmeliklerden Çevresel Etki Değerlendirme Yönetmeliği kullanım alanları geniş olan spor ve rekreasyon alanlarının tasarımında uyulması gereken ilkeleri düzenlemektedir. Bu yönetmeliğe göre spor ve rekreasyon alanında belirli bir proje ya da gelişmenin, çevre üzerindeki önemli etkilerinin belirlendiği yasal bir süreç söz konusudur.

Çevresel Etki Değerlendirmesi (Environmental Impact Assessment-ÇED) herhangi bir etkinlik sonucunda oluşabilecek ortam bozulmalarının önceden saptanmasını amaçlayan sistematik bir yaklaşımdır. 1983 yılında yürürlüğe giren ve 2003 yılında son halini alan 2872 sayılı Çevre 
Kanunu'nun 10. maddesi ÇED uygulamalarının başlatılmasını hukuksal bir esasa bağlamıştır ve bu anlamda bir standart oluşturmuştur. Gerçekleştirmeyi planladıkları faaliyetler sonucu çevre sorunlarına yol açabilecek kurum, kuruluş ve işletmelerin ÇED raporu hazırlamaları gerekmektedir. Bu raporda çevreye yapılacak tüm etkiler göz önünde bulundurularak, çevre kirliliğinin önlenmesi için alınacak önlemler belirtilmelidir.

ÇED uygulamasının amacı ekonomik ve sosyal gelişmeye engel olmaksızın, çevre değerlerini ekonomik politikalar karşısında korumak, planlanan bir faaliyetin yol açabileceği bütün olumsuz çevresel etkilerin önceden tespit edilip, gerekli tedbirlerin alınmasını sağlamaktır [28].

ÇED raporu ülkemizde spor ve rekreasyon alanları ile ilgili olarak kayak alanları ve mekanik tesisleri (telesiyej uzunluğu 1000 metre ve üzeri), orman alanlarının başka amaçla kullanıma dönüştürülmesi projeleri (golf sahası vb.), temalı parklar (halkın eğlenmek amacı ile para ödeyerek girdiği, geniş alanlara kurulu parklar), arabalar ve motosikletler için kalıcı yarış ve test sahaları ile spor kompleksleri ve hipodromlar için istenmektedir [28].

Sürdürülebilirlik uygulamalarında hedeflenen amaç, mutlak koruma bölgelerinde yer alan kaynak değerlerinin muhafaza edilmesi ve bozulmadan gelecek nesillere aktarılmasıdır. Spor ve rekreasyon etkinliklerinin ekonomik, sağlığı koruyucu, kültürel etkilerinden uzun süre yaralanılmak isteniyorsa, doğada yapılan etkinliklerde çevresel uyumun sağlanması gerekmektedir. Bu nedenle önemli çevresel etkileri olabilecek bütün yapılarda ÇED uygulamaları yapılmalıdır.

\section{TARTIŞMA VE SONUÇ}

Spor ve rekreasyon alanları ve organizasyonları geleneksel olarak kullanıcıların intiyaçları doğrultusunda tasarlanır ve düzenlenir. Geçtiğimiz yirmi yılı aşkın süredir yeşil tasarımlar ve sürdürülebilirlik kavramı kısıtlı kaynaklarla başa çıkmak ve tesislerin çevre üzerindeki etkisini azaltmak amacıyla kullanılması hedeflenen bir mekanizmaya dönüşmüştür. Varlığını gelecekte tamamen çevre ve insan üzerine kurgulaması beklenen spor endüstrisi için sürdürülebilirlik, ancak uzun dönemli olma stratejisi ile anlam kazanacaktır. Aksi takdirde artık, bugünkü kuşakların yararlanamadığı doğal kaynaklardan gelecek kuşakların yararlanması da mümkün olmayacaktır.

Kaliteli tasarım ve yönetim anlayışına sahip spor ve rekreasyon alanları, kirliliğe ve doğal kaynaklar üzerinde sürdürülemeyecek bir zorlamaya neden olmadan, kullanılabilir doğal kaynaklar üzerindeki basıncı azaltmalı, yerel ve kültürel geleneklerle bütünleşmelidir. Tarım ve kamu arazisinin değerlerine karşı duyarlı olmalıdır. Eğer spor ve rekreasyon faaliyetlerinin insan yaşamına ve sağlığına olumlu etkilerinden uzun süre yaralanılmak isteniyorsa, spor ve rekreasyon aktiviteleri ile çevresel uyumun sağlanması gerekmektedir. Ayrıca çevresel sürdürülebilirliğin sağlanmasında, teşvik niteliği taşıyan yasa veya yönetmeliklerle desteklenen ulusal ve bölgesel bir çevresel sürdürülebilirlik modeli geliştirilmelidir.

Sürdürülebilirlik ilkesinin spor ve rekreasyon alanlarına dönük hedefleri irdelenirse; bireysel araç kullanımının azaltılmasından, üretim-tüketim-atk zinciri dengesi ya da enerji sistemlerinde geri dönüşüm modellerinin benimsenmesine, ekolojik kayıpların azaltılmasından doğal yaşama ortamlarının korunmasına kadar pek çok farklı disiplinle ilişkili olduğu görülmektedir. Doğayı etkilemek yerine doğa ile uyumlu olmayı hedef alan ve doğaya zarar vermeksizin ondan faydalanmaya çalışan bir yaklaşımın benimsenmesi gerekmektedir. Bu ise doğada yapılan etkinliklerin hammaddesinin korunması anlamına gelmektedir.

Spor endüstrisiçevre değerlerinden en çok yararlanan endüstrilerden birisidir. Spor ve rekreasyon 
alanlarının tasarımında çevrenin, yerel halkın ve spor endüstrisinin birbiriyle kaynaşmadığı bir sürdürülebilir gelişmeden söz edilemez. Bu nedenle spor ve rekreasyon alanlarının tasarımında aşağıdaki ilkelere uyulmalıdır.

- Tesisin sürekli kullanımı sırasında ekosistemlerin gelişimlerinin devam etmesini sağlamak ve onları korumak

- Spor ve rekreasyon alanlarında tesisleri kullanan ve orada çalışan insanlar için son derece ihtiyaç duyulan kaliteli ve güvenli ortamı sunmak,

- Spor ve rekreasyon alanlarında içilebilir suyun başka amaçlarla kullanımını azaltmak,

- Ozon tabakasına zarar veren salınımları en aza indirmek,

- Tesislerin çevresinde yaşayan yerel halkın ve çevrede yaşayan türlerin üzerindeki gürültü etkisini en aza indirmek,

- Tesislerin çevresinde yaşayan yerel halkın ve çevrede yaşayan türlerin üzerindeki ışık etkisini en aza indirmek,

- Tesislerin yapım aşamasında ve kullanımında doğal kaynakların tüketimi ve zehirli atık tüketimini en aza indirmek,

- Çevredeki su kalitesini korumak için attk suların filtrelenmesi ve yeniden kullanımını sağlamak,

- Tesislerdeki tüm yenileme ve yapım faaliyetlerinde geri dönüşümlü malzemelerin kullanımını olabildiğince artırmak ve atık üretimini mümkün olduğunca azaltmak,

- Şu anki ve gelecekteki mutluluk için doğal rekreasyon alanlarının korunması ve buralardaki hızlı yapılaşmanın engellenmesi [14].

- Tasarlanan tesislerin toplu taşıma sistemlerine yakın olmasına dikkat edilmesi ve araba kirliliğini azaltmak için metro ya da demiryollarının yakınına konumlandırılması gerekmektedir.

Sonuç olarak, spor endüstrisi için sürdürülebilirlik, doğru planlama çalışmaları sonucunda ve yeşil tesislerin yardımıyla uzun vadede etkisini gösterecek ve doğal kaynakların kullanımının her geçen gün azalması ile de değerini artıracaktır.

\section{KAYNAKLAR}

1. WCED. World commission on environment and development, our common future: the brundtland report. Oxford University Press, Oxford; 1987.

2. Beyhan ŞG, Ünügür SM. Çağdaş gereksinmeler bağlamında sürdürülebilir turizm ve kimlik modeli. iTÜ Dergisi. 2005; 4(2): 79-87.

3. The International Olympic Committee. IOC Spor, çevre ve sürdürülebilir gelişme rehberi. Çeviren TMOK; 2008.

4. Karaman A. Sürdürülebilir çevre kavramı çerçevesinde ekolojik planlama yaklaşımı. Türkiye'de 17. Dünya Şehircilik Günü Kolokyumu: Kent ve Çevre 'Planlamaya Ekolojik Yaklaşım', Mimar Sinan Üniversitesi, İstanbul; 1993.

5. Treaty of European Union. [official] C 191, [updated. 1992 July 29] available from: http://eur-lex.europa.eu/en/treaties/ dat/11992M/htm/11992M.html\#0001000001

6. Carvalho OG. Sustainable development: is it achievable within the existing international political economy context?. Sustainable Development. 2001; 9, 61-73.

7. Nemli E. Çevreye duyarlı yönetim anlayışı. i̇.Ü.Siyasal Bilgiler Fakültesi Dergisi. 2001; 211-224.

8. Mazurkiewicz P. Corporate environmental responsibility: Is a common CSR framework possible? World Bank Discussion Paper 2005. [cited 2009 Aug 08]. Available from: http://siteresources.worldbank.org/EXTDEVCOMMENG/Resources/ csrframework.pdf.

9. Fried G. Managing sport facilities. Human Kinetics, Champaign, IL; 2005

10. Yost P. Green building programs-an overview. Building Standards, 2002; 12-16. 
11. Inskeep E. Tourism planning. An integrated and sustainable development approach, Van Nostrand Reinhold, New York; 1991.

12. Dick G. Green building basics. [updated 1999 Sep.] available from www.calrecycle.ca.gov/publications/ GreenBuilding/40099014.doc

13. Suttell R. The true cost of building green. Buildings, 2006; 100(4): 46-48.

14. Environmental Building News, Building Green on a Budget, 1999; 8(5), May available from: www.ebuild.com/Archives/ Features/Low_Cost/Low_Cost.html\#General

15. Chernushenko $D$, van der Kamp A, Stubbs D, Sustainable sport management: running and environmentally socially and economically responsible organization. Green \& Gold Inc. Ontorio, Canada, 2001.

16. Ries R, Bilec MM. The economic benefits of green buildings: A comprehensive case study. The Engineering Economist, 2006; 51(3): 259-295.

17. Smith J. Golf sahalarında çevreci yönetim. 1. Uluslararası Çevre ve Golf Konferansı: Türkiye Golf Federasyonu, 2006.

18. del Monte B. A sustainable approach. American School and University, 2006; 78(12): 19-22.

19. Gibson F, Lloyd J, Bain S, Hottell D. Green design and sustainability in sport and recreation facilities. The Smart Journal. 2008; 4(2): 26-32.

20. Loftness $\mathrm{V}$, Hakkinen B, Ada O, and Nevalainen A. Elements that contribute to healthy building design. Environmental Health Perspectives. 2007; 115(6): 965-970.

21. Çepel N, Ergün C. Küresel ısınma ve küresel iklim değişikliği. TEMA Yayın, İstanbul, 2002.

22. Trainer FE. The global sustainability crisis: the Implications for community. International Journal of Science Economics. 1997; 24(11): 1219-1240.

23. Greenpeace [homepage on the Internet]. How green games. Greenpeace's environmental assessment of the Sydney 2000 Olympics. [updated 2000 Sep. 01; cited 2009 Oct.03]. Available from: http://www.greenpeace.org/australia/ resources/reports/general/how-green-the-games-greenpea

24. Philip J. Solar-powered 'dragon' stadium in Taiwan. www.greenpacks.org. [updated 2009 May 19; cited 2009 Sept. 10] Available from: http://www.greenpacks.org/2009/05/19/solar-powered-dragon-stadium-in-taiwan/

25. Tiger Woods Dubai [homepage on the Internet]. Dubai: [updated 2009 March 18; cited 2009 Sept. 03]. Available from: http://www.tigerwoodsdubai.com

26. Budak S. Avrupa Birliği ve Türk çevre politikası, İstanbul, Büke Yayınları. 2000.

27. Çevre ve Orman Bakanlığı. Çevre Kanunu. [1983 9 Ağustos; elde ediliş tarihi 7 Aralık 2013] Erişim adresi: www2.cevreorman.gov.tr/yasa/k/2872.doc

28. ÇED Planlama Genel Müdürlüğü. ÇED Yönetmeliği. [2008 17 Temmuz; elde ediliş tarihi 12 Aralık 2013). Erişim adresi: http://www.cedgm.gov.tr/CED/AnaSayfa/yonetmelikler.aspx?sflang=tr. 